\title{
KEEFEKTIFAN MODEL PEMBELAJARAN ROLE PLAYING TERHADAP KEMAMPUAN BERBICARA
}

\author{
Siti Maria Ulfah ${ }^{1}$, M. Arief Budiman ${ }^{2}$ \\ 1,2 Pendidikan Guru Sekolah Dasar, Fakultas IImu Pendidikan,Universitas PGRI Semarang \\ email : sitimariaulfah558@gmail.com
}

\begin{abstract}
ABSTRAK
Peneliti ini bertujuan untuk mengidentifikasi efektif atau tidaknya model pembelajaran Role Playing terhadap kemampuan berbicara siswa kelas IV SD Negeri Rejosari 03 Semarang. Penelitian ini merupakan penelitian kuantitatif. Penelitian ini menggunakan One Group Pretest-Posttest Design. Populasi dalam penelitian ini adalah semua peserta didik kelas IV SD Negeri Rejosari 03 Semarang berjumlah 23 siswa tahun ajaran 2018/2019. Intrumen yang digunakan adalah 1) wawancara (2) Dokumentasi (3) Petunjuk soal. (4) Intrumen penilaian. Analisis Data menggunakan Teknis analisis data peneliti menggunakan uji normalitas dan uji hipotesis (uji-t). Uji normalitas digunakan untuk mengetahui kelas tersebut berdistribusi normal atau tidak. Uji hipotesis menggunakan uji t-test. Hasil penelitian ini diperoleh dengan melakukan analisis data awal, uji normalitas dengan uji lilliefors, dan analisis data akhir dengan uji T. Berdasarkan pada analisis data akhir yang telah dilakukan perhitungan uji T diperoleh thitung>ttabel yaitu 6,507>2,074 maka hipotesis dapat diterima, dengan demikian dapat disimpulkan bahwa pembelajaran dengan model Role Playing efektif terhadap kemampuan berbicara siswa kelas IV SD Negeri Rejosari 03 Semarang. Saran yang peneliti sampaikan yaitu agar Model Pembelajaran Role Playing dijadikan salah satu alternatif bagi guru dalam proses pemeblajaran terutama pada pembelajaran kemampuan berbicara siswa agar pembelajaran lebih aktif dan tidak membosankan.
\end{abstract}

Kata Kunci : model pembelajaran Role Playing, kemampuan berbicara

\begin{abstract}
This research aims to identify the effectiveness of the Role Playing learning model on the speaking ability of fourth grade students of SD Negeri Rejosari 03 Semarang. This is quantitative research. This study used One Group Pretest-Posttest Design. The population in this study were all fourth grade students of SD Negeri Rejosari 03 Semarang totaling 23 students in the 2018/2019 academic year. The instruments used were (1) interviewing, (2) Documentation, (3) Instructions for questions. (4) Assessment instruments. In technical data analysis researchers used the normality test and hypothesis test (t-test). The normality test is used to find out whether the class is normally distributed or not. Hypothesis test used the t-test.. The results of this study were obtained by conducting preliminary data analysis, doing normality test with lilliefors test, and performing final data analysis with $T$ test. Based on the final data analysis that has been calculated using $T$ test, it was obtained tcount> ttable that is $6.507>2.074$ then the hypothesis can be accepted. Thus it can be concluded that learning with the Role Playing model is effective towards the speaking ability of fourth grade students of SD Negeri Rejosari 03 Semarang. The researcher suggests to use Role Playing Learning Model as an alternative for teachers in the learning process especially for students' speaking skills so that learning process is more active and not boring.
\end{abstract}

Keywords: role playing learning models, student speaking skills 


\section{Pendahuluan}

Pendidikan adalah usaha sadar dan terencana untuk mewujudkan suasana belajar dan proses pembelajaran agar peserta didik secara aktif mengembangkan potensi dirinya untuk memiliki kekuatan spiritual pengendalian diri, kepribadian, kecerdasan, akhlak mulia serta keterampilan yang diperlukan dirinya, masyarakat, bangsa, dan negara. Oleh karena itu, setiap manuasia berhak mendapatkan pendidikan yang layak dan sebagaimana mestinya (UU Sisdiknas Nomor 20 Tahun 2003). Upaya meningkatkan kualitas pendidikan terus menerus dilakukan baik secara konvensional maupun inovatif. Hal tersebut lebih terfokus setelah diamanatkan bahwa tujuan pendidikan nasional adalah untuk meningkatkan mutu pada setiap jenis dan jenjang pendidikan. Jenis pendidikan adalah kelompok yang didasarkan pada kekhususan tujuan pendidikan suatu pendidikan yang meliputi pendidikan formal, nonformal, dan informal. Seorang guru harus mampu menciptakan suasana pembelajaran dengan baik. Baik dalam proses pemilihan pendekatan, model, dan metode yang dilakukan dengan mempertimbangkan situasi, kondisi, kebutuhan, dan karakteristik siswa yang dihadapi dalam rangka mencapai tujuan pembelajaran. Maka, guru harus teliti dalam memilih pendekatan, modeldan metode yang sesuai dengan siswanya agar tidak mempersulit siswa dalam belajar.

Dalam kegiatan pembelajaran ada tiga aspek penting diantaranya aspek kognitif, afektif, dan psikomotorik. Salah satunya yaitu aspek psikomotorik mengenai keterampilan siswa. Keterampilan yang ada meliputi keterampilan membaca, menulis, menyimak, dan berbicara. Siswa yang aktif dalam kegiatan pembelajaran akan menciptakan suasana kelas yang aktif juga, sehingga pembelajaran akan berjalan dengan baik karena ada aktivitas siswa yang mendukung dalam pembelajaran, seperti aktif bertanya maupun mengemukakan pendapat. Maka dari itu kemampuan siswa dalam berbicara harus banyak diasah agar siswa dapat berperan aktif dalam pembelajaran.

Berbicara merupakan salah satu keterampilan berbahasa yang membutuhkan suatu pemahaman dan kompetensi kebahasaan. Keterampilan berbicara pada dasarnya harus dimilik oleh semua orang yang dalam kegiatannya membutuhkan komunikasi, baik bersifat satu arah, timbal balik ataupun keduanya. Namun, keterampilan berbicara tidaklah dimiliki oleh seseorang secara otomatis. Keterampilan berbicara yang baik dapat dimiliki dengan cara mengolah maupun melatih seluruh potensi yang ada (Iskandar wassid dan Sunendar, dalam Antarika, 2016).

Keterampilan berbicara dalam berbagai situasi dan tujuan merupakan hal yang mendasar bagi siswa, seperti yang dijelaskan oleh Norton (dalam Sukreni, dkk, 2014:2) mengartikan bahwa "keterampilan anak berbicara merupakan hal yang sangat mendasar untuk keberhasilannya dalam setiap bagian kehidupan, baik di sekolah maupun di rumahnya.

Kenyataannya saat ini kemampuan berbicara siswa dalam kegiatan pembelajaran di Indonesia jauh dari kata baik, karena secara menyeluruh para siswa masih sulit untung berbicara dalam kegiatan pembelajaran. Siswa hanya mampu menyampaikan suatu gagasan satu dua kata saja, siswa belum mampu menyampaikan gagasan secara menyeluruh.

Dalam hal ini guru juga kurang kreatif menggunakan model pembelajaran. Karena masih di jumpai banyak guru yang menggunakan metode konevensional seperti ceramah saat pembelajaran dan disisi lain siswa hanya diam, mendengarkan serta mencatat sehingga siswa cenderung akan mudah bosan dan tidak tertarik terhadap pembelajaran dan pembelajaranpun berjalan monoton.

Beberapa penelitian terdahulu yaitu diantaranya (1) Keefektifan Penerapan Metode Bermain Peran (Role Playing) pada Pembelajaran Bahasa Indonesia Materi Pesan melalui Telepon di Kelas IV Sekolah Dasar Negeri Purbalingga Kidul 1 Kabupaten Purbalingga (2) Keefektifan Metode Role Playing Terhadap Keaktifan dan Kerja Sama Siswa dalam Pembelajaran IPS (3) Keefektifan Metode Role Playing Terhadap Hasil Belajar Pendidikan Kewarganegaraan Materi Keputusan Bersama Siswa Kelas V Sekolah Dasar Negeri 3 Randugunting Kota Tegal. 
Dengan hasil penelitiannya yaitu (1) Hasil penelitian yang telah dilaksanakan membuktikan adanya perbedaan yang signifikan antara pembelajaran yang menerapkan metode bermain peran (role playing) dengan yang menerapkan metode pemberian tugas. Ini dibuktikan dengan penghitungan uji independent sample t-test menggunakan SPSS versi 17, nilai thitung $>t$ tabelyaitu 2,515 $>2,005$ serta nilai signifikan yang kurang dari 0,05 yaitu 0,015. Rata-rata aktivitas belajar peserta didik yang menerapkan metode bermain peran (role playing) sebesar $80,84 \%$, sedangkan rata rata aktivitas di kelas control $71,29 \%$. Kedua hasil tersebut dapat disimpulkan, bahwa penerapan metode bermain peran (role playing) terbukti efektif dalam meningkatkan hasil belajar dan aktivitas peserta didik dalam pembelajaran dibandingkan dengan penerapan (2) Berdasarkan hasil penelitian dan pem-bahasan maka disampaikan simpulan sebagai berikut. Pertama metode role playing lebih efektif secara signifikan terhadap peningkatan keaktifan siswa dibandingkan dengan metode ceramah dalam pembelajaran IPS denga nilai signifikansi kurang dari 0,05. Rata-rata hasil posttest siswa pada metode role playing (keaktifan siswa $=80,91$ ) dan metode ceramah (keaktifan siswa $=77,59$ ). Dari hasil observasi menunjukkan bahwa siswa yang aktif dengan persentase tertinggi pada kelas kontrol yaitu siswa mengemukakan pendapat di kelas $78,12 \%$ dan kelas eksperimen yaitu siswa ber-tanya apabila yang disampaikan guru kurang jelas $89,06 \%$. (3) Hasil penelitian berupa hasil uji hipotesis terhadap hasil belajar siswa menunjukan thitung sebesar 2,614 dan ttabel sebesar 1,998 (thitung > ttabel), maka Ho ditolak dan Ha diterima.

Jadi dapat disimpulkan bahwa terdapat perbedaan hasil belajar yang signifikan antara siswa kelas eksperimen yang mendapat perlakuan metode role playing dengan siswa kelas kontrol yang mendapat perlakuan metode ceramah pada materi keputusan bersama. Hasil belajar siswa yang mendapat perlakuan metode role playing lebih baik daripada yang mendapat perlakuan metode ceramah, sehingga guru perlu mempertimbangkan menerapkan metode role playing pada pembelajaran PKn di SD. Penelitian tersebut dilaksanakan di tahun 2012, 2017, 2013, kemudian peneliti di tahun 2018/2019 ingin membuktikan kembali apakah dampak positif dari model pembelajaran Role Playing di tahun 2012, 2017, 2013 masih berdampak positif di tahun 2018/2019 atau tidak. Penelitian terdahulu dilaksanakan di Purbalingga, Marioriawa, Randugunting Tegal yang dapat diketahui masing-masing daerah tersebut karakter siswa berbeda, faktor lingkungan berbeda, kompetensi yang dimiliki guru berbeda. Maka dari itu penelitiingin membuktikan apakah model pembelajaran Role Playing yang telah diterapkan di daerah tersebut bisa juga diterapkan di semarang atau tidak.

Berdasarkan hasil wawancara dengan Boga Hari Suharnowo siswa kelas IV SD Negeri Rejosari 03 Semarang pada saat guru menyampaikan materi, guru hanya menggunakan metode ceramah dan tidak mengemas pembelajaran yang menarik bagi siswa. Selain itu berdasarkan hasil observasi pada saat proses pembelajaran dapat disimpulkan bahwa kemampuan siswa dalam keterampilan berbicara kurang. Hal itu dapat dibuktikan dengan hasil pengamatan di dalam kelas sebagai berikut:

Tabel 1. Nilai Harian Berbicara

\begin{tabular}{lllll}
\hline No & KKM & Jumlah & Presentasase & Keterangan \\
\hline 1 & $<75$ & 18 siswa & $78 \%$ & Tidak Tuntas \\
2 & $>75$ & 5 siswa & $22 \%$ & Tuntas \\
\hline
\end{tabular}

(Sumber: Data NilaiHarian)

Dari Tabel 1 dapat dilihat nilai harian kemampuan berbicara siswa Kriteria Ketuntasan Minimal (KKM) 75, sebanyak ini dimulai dengan siswa disediakan teks atau naskah drama, kemudian siswa memerankan tokoh yang ada di dalam drama tersebut.

Salah satu model pembelajaran yang sesuai untuk mengasah kemampuan berbicara siswa adalah model Role Playing. Model pembelajaran Role Playing banyak memberikan manfaat kepada siswa karena dengan pembelajaran Role Playing siswa dapat lebih mengembangkan potensi yang ada pada dirinya dan dapat menambah aktivitas dan 
kreativitas dalam proses pembelajaran. Menurut Djamarah dan Zaini (dalam Sukreni, dkk, 2014:3), salah satu keunggulan model Role Playing adalah bahasa lisan siswa dapat dibina menjadi bahasa yang baik agar mudah dipahami orang lain.

Beberapa Penelitian terdahulu yang pernah dilakukan terkait penerapan model pembelajaran Role Playing dalam kegiatan pembelajaran antara lain adalah penelitian yang telah dilakukan oleh Ahmad Syarifuddin (2014) yang dimuat dalam jurnal penelitian dengan judul Pengaruh Metode Role Playing Terhadap Keterampilan Berbicara Siswa Pada Mata Pelajaran Bahasa Indonesia Kelas V di Madrasah Ibtidaiyah Wathoniyah Palembang. Berdasarkan hasil penelitian ini bahwa hasil keterampilan berbicara siswa pada mata pelajaran Bahasa Indonesia sebelumditerapkannya metode role playing yang tergolong tinggi (baik) sebanyak 6 orang siswa $(21,43 \%)$, yang tergolong sedang sebanyak 12 orang siswa $(42,86 \%)$, dan yang tergolong rendah sebanyak 10 orang siswa $(35,71 \%)$. Selanjutnya hasil keterampilan berbicara siswa setelah diterapkannyametode role playing yang tergolong tinggi (baik) 9 orang siswa (32\%), tergolong sedang sebanyak 13 orang siswa (47\%), dan yang tergolong rendah sebanyak 6 orang siswa (21\%). Dari data di atas dapat disimpulkan bahwa kemampuan berbicara siswa dalam pembelajaran dengan menggunakan model pembelajaran Role Playing.

Berdasarkan pendapat tersebut, dapat disimpulkan bahwa model pembelajaran Role Playing adalah suatu model pembelajaran yang berorientasi agar siswa dapat melatih kemapuan berbicara secara menyeluruh. Berdasarkan uraian di atas, maka penulis merasa perlu mengadakan penelitian dengan judul keefektifan model pembelajaran Role Playing terhadap kemampuan berbicara siswa kelas IV SD Negeri Rejosari 03 Semarang tahun 2018/2019.

18 siswa (78\%) tidak tuntas atau masih di bawah KKM. Sedangkan hanya 5 siswa $(22 \%)$ tuntas atau sudah mencapai KKM.

Solusi yang dapat digunakan untuk mengatasi masalah yang dihadapi adalahdengan mengembangkan model pembelajaran yang dapat meningkatkan kemampuan siswa dalam keterampilan berbicara menggunakan model Role Playing. Penerapan model pembelajaran.

\section{Metode}

Metode yang dipakai dalam penelitian ini adalah metode penelitian kuantitatif dengan fokus penelitian satu kelas eksperimen yang digunakan. Yang digunakan dalam penelitian ini adalah Pre Experimental Design dengan jenis One-Group Pretest-posttest Design.Populasi dalam penelitian ini adalah siswa kelas IV SD Negeri Rejosari 03 Semarang.Teknik pengumpulan data yang digunakan pada penelitian ini adalah metode tes dan non tes.Analisis data awalmenggunakanUjiNormalitas,misalkan sampel acak dengan menggunakan X1, $\mathrm{X} 2, \ldots, \mathrm{Xn}$. Analisis data akhirmenggunakanUji T.

\section{Hasil Dan Pembahasan}

Penelitian ini berjudul Kefektifan Model Pembelajaran Role Playing Terhadap Kemampuan Berbicara Siswa Kelas IV SD Negeri Rejosari 03 Semarang.Pada waktu dilakukan observasi di SD Negeri Rejosari 03 Semarang didapatkan masalah dalam pembelajaran Bahasa Indonesia pada siswa kelas IV. Masalah yang dialami yaitu rendahnya nilai pada aspek kemampuan berbicara siswa yang disebabkan oleh kurangnya inovasi guru dalam menggunakan model pembelajaran.

Untuk mengatasi masalah tersebut maka perlu dilakukan sebuah pembelajaran baru yang inovatif sehingga mampu menarik perhatian siswa dalam pembelajaran.Peneliti mencoba memberikan solusi dengan memberikan perlakuan dengan menggunakan model pembelajaran Role Playing.

Desain penelitian yang digunakan dalam penelitian ini yaitu berupa One Group Pretest Posttest Design dengan menggunakan satu kelompok kelas yang akan diukur peningkatanpada keterampilan menulisnya melalui uji pretest dan posttest. Hasil belajar pretest 
didapatkan sebelum siswa diberikan perlakuan dengan menggunakan model pembelajaran Role Playing dengan tujuan untuk mengukur kemampuan awal siswa.Sedangkan hasil belajar posttest didapatkan setelah siswa diberikan perlakuan dengan menggunaka model pembelajaran Role Playing, sehingga peneliti dapat mengetahui peningkatan kemampuan berbicara siswa.

Instrumen yang dipilih dalam penelitian ini yaitu berupa tes yang berisikan 4 butir petunjuk soal. Hasil penelitian ini menunjukkan bahwa nilai kemampuan berbicara siswa pada uji pretest didapatkan nilai terendah sebesar 35, nilai tertinggi sebesar 75 dan nilai rata-rata sebesar 63. Siswa yang tuntas KKM 75 pada uji pretest sebanyak 4 siswa dan yang tidak tuntas 19 siswa. Sedangkan pada uji posttest didapatkan nilai terendah sebesar 60, nilai tertinggi sebesar 95. Dan nilai rata-rata sebesar 76. Pada hasil uji posttest menunjukkan bahwa siswa yang tuntas KKM 75 sebanyak 18 siswa dan siswa yang tidak tuntas sebanyak 5 siswa.

Dengan melihat hasil penelitian tersebut maka dapat disimpulkan bahwa terdapat peningkatan kemampuan berbicara siswa setelah diberikan perlakuan dengan menggunakan model pembelajaran Role Playing.Data hasil penelitian yang telah didapatkan kemudian dilakukan uji normalitas dengan menggunakan uji lilliefors.Dengan menggunakan $\mathrm{N}=23$ dan taraf signifikan $5 \%$ maka diperoleh Ltabel=0,173. Hasil ujinormalitas pada uji pretest didapatkan nilai Lhitung=0,151. Karena didapatkan nilai Lhitung<Ltabel maka data yang didapatkan berasal dari populasi yang berdistribusi normal.

Data penelitian yang normal tersebut selanjutnya dilakukan pengujian hipotesis dengan menggunakan uji t yang bertujuan untuk mengetahui keefektifan model pembelajaran Role Playing.Dengan jumlah $\mathrm{N}=23-1=37$ dan taraf signifikan $5 \%$ didapatkan nilai Ttabel=2,074, hasil dari uji t didapatkan nilai Thitung $=6,349$. Karena diperoleh nilai Thitung $>$ Ttabel maka hipotesis yang diajukan diterima.Dengan demikian berdasarkan uji t dapat disimpulkan bahwa model pembelajaran Role Playing efektif terhadap kemampuan berbicara siswa kelas IV SD Negeri Rejosari 03 Semarang.

Penelitian ini relevan dengan penelitian yang sebelumnya, yang menyatakan bahwa model pembelajaran Role Playing efektif terhadap kemampuan berbicara siswa. Kajian penelitian yang relevan dengan penelitian ini yaitu didasarkan pada penelitian yang dilakukan sebelumnya oleh Wenti Antarika (2016) yang berjudul "Penerapan Model Pembelajaran Role Playing Untuk Meningkatkan Keterampilan Bermain Drama Siswa Kelas XI IPS 1 SMA Negeri 1 Way Tuba Way Kanan Tahun Pelajaran 2015/2016". Dalam penelitian ini mengkaji tentang penerapan pembelajaran pada keterampilan bermain peran dengan menggunakan model pembelajaran Role Playing.Dimana setelah dilakukan penelitian dengan menggunakan model pembelajaran Role Playing dapat meningkatkan aktivitas siswa dalam pembelajaran.

Penelitian yang relevan oleh Ernani (2016) yang berjudul "Pengaruh Metode Role Playing Terhadap Keterampilan Berbicara Siswa Pada Mata Pelajaran Bahasa Indonesia Kelas V Di Madrasah Ibtidaiyah Wathoniyah Palembang". Dalam penelitian ini mengkaji tentang adanya pengaruh model Role Playing terhadap keterampilan berbicara siswa pada mata pelajaran Bahasa Indonesia di Madrasah Ibtidaiyah Wathoniyah Palembang. Hasil penelitian yang didapatkan oleh Wenti Antarika dan Ernani relevan dengan penelitian ini.Kajian penelitian ini dijadikan salah satu rujukan oleh peneliti dalam melaksanakan penelitian.Sehingga dapat membuat sebuah penelitian yang lebih baik dari penelitian sebelumnya.

Penelitian yang relevan oleh Sukreni (2013/2014) yang berjudul "Pengaruh Model Pembelajaran Role Playing Berbasis Penilaian Kinerja Terhadap Keterampilan Berbicara Pada Pelajaran Bahasa Indonesia Siswa Kelas V SD". Hasil dari penelitian ini menunjukkan bahwa rata-rata nilai keterampilan berbicara kelas eksperimen lebih tinggi dari pada kelas kontrol $(77,61>68,32)$. Hasil analisis uji t diperoleh t hitung $=3,43>$ Ttabel $=2,00$ pada taraf signifikansi $5 \%$ dan $\mathrm{dk}=71$, sehingga $\mathrm{H} 0$ ditolak dan $\mathrm{Ha}$ diterima, yang artinya terdapat perbedaan yang signifikan keterampilan berbicara pada siswa yang mengikuti pembelajaran Role Playing berbasis penilaian kinerja dan siswa yang mengikuti pembelajaran konvensional. Dengan demikian, dapat disimpulkan bahwa terdapat pengaruh model pembelajaran Role Playing berbasis penilaian kinerja kelas V SD Gugus Kapten Japa Tahun Ajaran 2013/2014. 
Penelitian relevan dari Basri (2017) yang berjudul "Penerapan Model Pembelajaran Role Playing Untuk Meningkatkan Hasil Belajar Bahasa Indonesia Siswa Kelas V Sdn 032 Kualu Kecamatan Tambang". Hasil dari penelitian ini Penelitian ini dilakukan 2 siklus, dengan masing-masing siklus terdiri dari dua pertemuan serta dua kali tes harian. Agar penelitian tindakan kelas berhasil, para peneliti menetapkan tahap perencanaan tindakan, tindakan, observasi dan refleksi. Berdasarkan hasil penelitian, dapat disimpulkan bahwa aktivitas guru dalam pembelajaran bermain peran implementasi, pada siklus I rata-rata aktivitas guru adalah sebesar $62,50 \%$ pada kategori kurang cantik, dan aktivitas guru pada siklus II sebesar 84,72. $\%$ di kedua kategori satu kali. Dengan demikian ada peningkatan aktivitas guru sebesar $22,22 \%$ dari siklus pertama ke siklus kedua. Rata-rata aktivitas siswa pada siklus I persentase aktivitas siswa dalam belajar cenderung meningkat. Pada pertemuan pertama dengan rata-rata aktivitas siswa yaitu $61,25 \%$ dengan kategori cukup. Pada pertemuan kedua meningkat ratarata aktivitas siswa yaitu $81,25 \%$ dengan kategori cukup. Rata-rata peningkatan aktivitas siswa dari siklus I ke siklus II 20,00\%. Kelas dianggap selesai ketika kelas telah mencapai skor $85 \%$ dari jumlah karena atau untuk KKM 75 maka kelas dikatakan selesai (90,00\%). Dari uraian di atas menunjukkan bahwa penerapan model pembelajaran dapat meningkatkan hasil bermain peran pembelajaran siswa kelas V SDN 032 Kualu Kecamatan Tambang Indonesia, dapat disimpulkan bahwa hipotesis diterima sebagai tindakan nyata.

Penelitian relevan dari Syarifuddin (2016) yang berjudul "Pengaruh Metode Role Playing Terhadap Keterampilan Berbicara Siswa Pada Mata Pelajaran Bahasa Indonesia Kelas V di Madrasah Ibtidaiyah Wathoniyah Palembang". Berdasarkan hasil penelitian ini bahwa hasil keterampilan berbicara siswa pada mata pelajaran Bahasa Indonesia sebelum diterapkannya metode role playing yang tergolong tinggi (baik) sebanyak 6 orang siswa $(21,43 \%$ ), yang tergolong sedang sebanyak 12 orang siswa (42,86\%), dan yang tergolong rendah sebanyak 10 orang siswa $(35,71 \%)$. Selanjutnya hasil keterampilan berbicara siswa setelah diterapkannya metode role playing yang tergolong tinggi (baik) 9 orang siswa (32\%), tergolong sedang sebanyak 13 orang siswa (47\%), dan yang tergolong rendah sebanyak 6 orang siswa (21\%). Dengan demikian dapat disimpulkan bahwa dari perhitungan di atas didapat $t 0>$ ttdengan hasil yaitu 2,052,77. Jadi, karena t0 lebih besar daripada tt maka hipotesis nihil yang diajukan ditolak, ini berarti bahwa adanya pengaruh penerapan metode role playing terhadap keterampilan berbicara siswa pada mata pelajaran Bahasa Indonesia di Madrasah Ibtidaiyah Wathoniyah Palembang.

Menurut Hamalik (dalam Nurzannah, 2016) bahwa model pembelajaranRole Playing adalah model pembelajaran dengan cara memberikan peran-peran tertentu kepada peserta didik dan mendramatisasikan peran tersebut. Role Playing adalah salah satu model pembelajaran interaksi sosial yang menyediakankesempatan kepada murid untuk melakukan kegiatan-kegiatan belajar secara aktif.

Pada penelitian ini sesuai dengan teori yang dikemukakan oleh Thorndike yang menyatkan bahwa belajar adalah proses interaksi antara stimulus dan respon. Stimulus yaitu apa saja yang dapat merangsang terjadinya kegiatan belajar seperti pikiran, perasaan, atau hal-hal lain yang dapat ditangkap melalui alat indera. Respon adalah reaksi yang dimunculkan peserta didik ketika belajar, yang juga dapat berupa pikiran, perasaan atau gerakan/tindakan. Dalam penelitian ini siswa diberikan stimulus berupa pemberian naskah drama Raja Purnawarman, kemudian setelah diberikan naskah cerita tersebut siswa mulai membaca dan belajar mempraktikkannya. Teori tersebut telah terbukti dengan hasil penelitian yang didapatkan selama penelitian berlangsung.Selain itu juga teori tersebut sejalan dengan kenyataan saat berada di lapangan.Pola interaksi siswa selama berlangsungnya kegiatan belajar menagajar pada saat penelitian sangat baik. Siswa sangat antusias dalam mengikuti pembelajaran, siswa bersifat lebih aktif dan munculnya rasa ingin tahu siswa yang tinggi.

Langkah-langkah dalam penelitian ini, pada hari pertama siswa belajar Bahasa Indonesia keterampilan berbicara dengan model konvensional. Kemudian siswa mempraktikkan maju ke depan untuk berbicara mengenai cerita Raja Purnawarman. Setelah semua siswa maju, siswa dibentuk menjadi beberapa kelompok dan diberikan satu teks naskah drama cerita Raja Purnawarman yang telah dipersiapka sebelumnya oleh peneliti untuk 
dipelajari.Kemudian, hari kedua penelitian siswa diminta untuk mempraktikkan naskah drama bersama dengan kelompoknya yang sudah dipelajari pada hari sebelumnya.Setelah mempraktikkan, siswa diminta untuk menceritakan kembali cerita yang ada di dalam naskah.

Penerapan model pembelajaran Role Playing pada penelitian ini menimbulkan reaksi: 1. Konflik interpersonal. Terdapat permasalahan yang dialami siswa yaitu siswa dituntut untuk berpikir bagaimana cara menguasai naskah drama. Kemudian siswa mampu menemukan teknik belajar penguasaan naskah drama yang diberikan, 2. Relasi antar kelompok. Saling membantu anggota kelompok untuk belajar memahami percakapan yang ada dalam naskah. 3 . Dilema individu. Ketika sebagian kecil teman dari anggota kelompoknya belum bisa menghafal percakapan maka semua anggota mengulang-ulang latihan percakapan naskah drama, dan yang sudah bisa menghafal tidak bosan untuk mengulanginya, dan 4. Masalah historis atau kontemporer. Ketika ada teman yang belum bisa menghafal maka siswa belajar untuk memutuskan diadakannya latihan lagi atau tidak.

Sistem sosial yang timbul dalam penelitian ini yang menerapkan model pembelajaran Role Playing: siswa mampu mengekspresikan sesuai dengan percakapan yang ada, siswa saling mendapatkan arahan satu sama lain dalam cara berekspresi atau bertindak, siswa berlatih berbicara dan menghafal percakapan.

Sistem pendukung yang timbul dari penelitian ini yang menerapkan model pembelajaran Role Playing yaitu peneliti menyiapkan teks drama tentang Raja Purnawarman yang sebelumnya siswa hanya membaca cerita Raja Purnawarman pada buku tematik saja.

Dampak pengiring yang timbul dari penelitian yang menerapkan model pembelajaran Role Playing yaitu siswa mendapatkan pengalaman baru mempraktikkan suatu drama, siswa belajar berinteraksi dan berlatih berbicara.

Kelebihan dalam penerapan model pembelajaran Role Playing: 1. Siswa lebih antusias dalam proses pembelajaranSiswa berlatih untuk mengin, 2. gat percakapan yang ada pada naskah, 3. Siswa berlatih untuk berinteraksi satu sama lain di dalam suatu kelompok. 4. Siswa berlatih mengekspresikan percakapan yang ada pada naskah 5 . Siswa berlatih untuk bericara dengan suara yang keras dan intonasi yang tepat. 6 . Siswa belatih untuk menumbuhkan rasa kepercayaan diri menujukkan hasil drama dari kelompoknya 7. Siswa berlatih untuk saling tolong menolong antar anggota kelompok. Teman yang sudah bisa menghafal naskah pecakapan, membantu teman yang belum bisa menghafal naskah percakapan yang ada. Siswa yang memiliki bakat berbicara, akan terasah lagi dengan adanya penerapan model pembeleajaran Role Playing

Kelemahan untuk penerapan model pembelajaran Role Playing pada saat penelitian: 1. Memerlukan waktu yang cukup lama untuk mempersiapkan drama, 2. Siswa gaduh di kelas karena masing-masing kelompok saling berbicara dengan nada yang keras, 3. Siswa yang pada dasarnya pemalu, maka siswa tersebut akan merasa tidak senang pada saat proses pembelajaran berlangsung, 4. Siswa saling mengejek kelompok yang sedang mempraktikkan drama di depan kelas, yang mengakibatkan proses pembelajaran membutuhkan waktu yang lama.

Walaupun pada model pembelajaran Role Playing terdapat kelemahan, tetapi kelemahan ini tidak mengurangi kelebihan-kelebihan yang dimiliki. Terbukti bahwa model pembelajaran Role Playing efektif terhadap kemampuan berbicara siswa SD Negeri Rejosari 03 Semarang.

\section{Simpulan dan Saran}

Penelitian dengan menggunakan model pembelajaran Role Playing efektif terhadap kemampuan berbicara siswa kelas IV SD Negeri Rejosari 03 Semarang. Hal ini dibuktikan dengan nilai siswa yang mencapai KKM 75 sebanyak 18 siswa $(78 \%)$ tuntas dengan nilai tertinggi 95, sedangkan siswa yang belum mencapai KKM sebanyak 5 siswa (22\%) tidak tuntas dengan nilai terendah 60. Pembelajaran dengan model Role Playing menciptakan 
pembelajaran yang berbeda dengan sebelumnya, dimana pembelajaran ini lebih efektif, menyenangkan dan membuat siswa lebih aktif dalam kegiatan pembelajaran. Siswa menjadi lebih mudah dalam mengasah kemampuan berbicaranya. Dengan kata lain pembelajaran dengan menggunakan model Role Playing efektif terhadap kemampuan berbicara siswa kelas IV SD Negeri Rejosari 03 Semarang.

\section{Daftar Rujukan}

Anggriani, dkk.2017."Keefektifan Metode Role Playing Terhadap Keaktifan dan Kerja Sama Siswa dalam Pembelajaran IPS". Artikel. https://journal.uny.ac.id/index.php/hsjpi/article/view/11017/11353.Diakses 6 Februari 2019.

Antarika, Wenti.2016."Penerapan Model Role PlayingUntukMeningkatkanKeterampilanBermain Drama SiswaKelas XI".Artikel.Diakses 12 Oktober 2018.

Ariani, Deasy.2013."Peningkatan Motivasi Dan Keterampilan Berhitung Melalui Penggunaan Media Batang Napier Dalam Pembelajaran Matematika Kelas IV SDN 03 Rejosari Kudus".Skripsi.http://eprints.ums.ac.id./Diakses 10 Oktober 2018.

Aritonang, K. T. (2008). Minat dan motivasi dalam meningkatkan hasil belajar siswa. Jurnal Pendidikan Penabur, 7(10), 11-21.Diakses 30 Desember 2018.

Asmiranti.2016."HasilBelajar".repository.unpas.ac.id.artikel.Diakses30 Desember 2018.

Basri, Hasan.2017."Penerapan Model Pembelajaran Role Playing Untuk Meningkatkan Hasil Belajar Bahasa Indonesia Siswa KelaS V SDN 032 Kualu Kecamatan Tambang".

https://media.neliti.com/media/publications/258052-penerapan-model-pembelajaran-role-playine1a411a7.pdf.Artikel.Diakses 21 Jnuari 2019

Ernani.2016."Pengaruh MetodeRole Playing TerhadapKeterampilanBerbicaraSiswaPada Mata PelajaranBahasalndonesia Kelas $\mathrm{V}$ Di Madrasah IbtidaiyahWathoniyah Palembang".Artikel.Diakses 12 Oktober 2018.

Fahrudin, Ahmad.2017."Perbedaan Hasil Belajar Matematika Siswa Yang Diajarkan Menggunakan Quantum Learning Teknik Mind Mapping dengan Cooperative Learning Teknik Jigsaw Di SMP Negeri 18 Tangerang".

Faizah, Umi.2009."Peran Mata Kuliah Retorika Dalam Pembinaan Budi Pekerti Dan Moral Bangsa (Studi Kasus Mahasiswa Pendidikan Bahasa Dan Sastra Indonesia Universitas Muhammadiyah Purworejo)".Artikel.http://download.portugalgaruda.org/.Diakses 11 Oktober 2018.

Hidayat, Dayat."Pentingnya Pelajaran Bahasa Indonesia Pada Tingkat Pendidikan Dasar SD Dan SMP Terintegrasi Dengan Pelajaran Lain (Fenomena Yang TerjadiDiSekelilingSiswa)".Skripsi.http://openjournal.unpam.com/.Diakses 10 Oktober 2018.

Kisnawaty, P.2013."Keefektifan Metode Role Playing Terhadap Hasil Belajar Pendidikan Kewarganegaraan Materi Keputusan Bersama Siswa Kelas V Sekolah Dasar Negeri 3 Randu gunting Kota Tegal”. https://lib.unnes.ac.id/17346/1/1401409126.pdf.Diakses 6 Februari 2019. 
Nurzannah, N.2016."Menggunanakan Model Pembelajaran Playing".repository.unpas.ac.id.artike.

Purwandari.2012."Keefektifan Penerapan Metode Bermain Peran (Role Playing) pada Pembelajaran Bahasa Indonesia Materi Pesan melalui Telepon di Kelas IV Sekolah Dasar Negeri Purbalingga Kidul 1 Kabupaten Purbalingga".Skripsi. https://lib.unnes.ac.id/18812/1/1402408098.pdf.Diakses 6 Februari 2019

Sisdiknas.file://G:/SKRIPSI/Proposal/ARTIKEL\%20\&\%20JURNAL/sisdiknas.pdf

Sukreni, Ni Nyoman. Dkk. 2014."Pengaruh Model Pembelajaran Role Playing Berbasis Penilaian Kinerja Terhadap Keterampilan Berbicara Pada Pelajaran Bahasa Indonesia Siswa Kelas V SD”.Artikel.Diakses 10 Oktober 2018.

Syarifuddin, Ahmad.2016."Pengaruh Metode Role Playing Terhadap Keterampilan Berbicara Siswa Pada Mata Pelajaran Bahasa Indonesia Kelas V di Madrasah Ibtidaiyah Wathoniyah. 